\title{
Evolutionary history of two endemic Appalachian conifers revealed using microsatellite markers
}

\author{
Kevin M. Potter · John Frampton • \\ Sedley A. Josserand · C. Dana Nelson
}

Received: 6 February 2009/Accepted: 19 August 2009/Published online: 10 September 2009

(C) Springer Science+Business Media B.V. 2009

\begin{abstract}
Fraser fir (Abies fraseri [Pursh] Poir.) and intermediate fir (Abies balsamea [L.] Mill. var. phanerolepis Fern.) exist in small populations in the Appalachian highlands of the southeastern United States. We used ten nuclear microsatellite markers to quantify genetic variation within Fraser fir and intermediate fir, and to examine their evolutionary relationships with the widespread balsam fir (Abies balsamea [L.] Mill.). We found little genetic differentiation among these taxa, suggesting that Fraser fir might best be classified as a variety of balsam fir. The results further appear to reject the hypothesis that intermediate fir was of hybrid origin between two comparatively distantly related species. Low levels of genetic diversity suggest that intermediate fir and Fraser fir have undergone at least some genetic degradation since postPleistocene isolation. The results may prove important for
\end{abstract}

K. M. Potter $(\varangle)$ J J. Frampton

Department of Forestry and Environmental Resources, North

Carolina State University, Raleigh, NC 27695-8002, USA

e-mail: kpotter@ncsu.edu

J. Frampton

e-mail: john_frampton@ncsu.edu

S. A. Josserand · C. Dana Nelson

Southern Institute of Forest Genetics, USDA Forest Service,

Southern Research Station, 23332 Mississippi 67, Saucier,

MS 39574, USA

e-mail: sjosserand@fs.fed.us

C. Dana Nelson

e-mail: dananelson@fs.fed.us

Present Address:

K. M. Potter

Department of Forestry and Environmental Resources, Forest

Sciences Laboratory, North Carolina State University, 3041

Cornwallis Road, Research Triangle Park, NC 27709, USA in situ and ex situ gene conservation efforts for Fraser fir and intermediate fir, which are imperiled by an exotic insect and by global climate change.

Keywords Biogeography · Pleistocene · Migration · Population genetics $\cdot$ Microsatellite markers $\cdot$ Abies

\section{Introduction}

The North American balsam firs (section Balsamea Englm.) present an interesting study on the difficulty of Abies (true fir) taxonomy and on the importance of climate-related migration to the recent evolutionary history of forest tree species. Section Balsamaeae of Abies is traditionally separated into four taxa, all of which exist in cool and wet boreal forests in the higher elevations and latitudes of the North American continent. Subalpine fir (Abies lasiocarpa [Hook.] Nutt.) is largely restricted to high western forests from Alaska to Arizona (Alexander et al. 1990). Balsam fir (Abies balsamea [L.] Mill.) occurs throughout eastern and central Canada, as well as the Great Lakes and northeastern United States, with individual trees reaching their greatest size and age in the eastern part of the boreal region in Canada (Bakuzis and Hansen 1965). Finally, two Abies taxa are native to the southeastern United States, where both are restricted to small populations in the high elevations of the Appalachian Mountains. A variety of balsam fir, known as intermediate fir or Canaan fir (Abies balsamea var. phanerolepis Fern.), mostly occurs in scattered high-elevation bogs in West Virginia (Stephenson and Adams 1986) and on mountaintops in Shenandoah National Park in Virginia (Mazzeo 1966). Fraser fir (Abies fraseri [Pursh] Poir.) is endemic to a handful of island-like populations on mountain 
ridges in the southern Appalachians of North Carolina, Tennessee and Virginia, almost entirely at elevations above 1,300 m (Whittaker 1956; Busing et al. 1993).

Morphological and genetic similarities among Fraser fir, intermediate fir and the widespread balsam fir have raised questions about the origin of the two Southeastern fir taxa and have provoked debate regarding their taxonomic status. Studies of cone and needle morphology (Roller 1966; Robson et al. 1993) and resin chemistry (Zavarin et al. 1970; Zavarin and Snajberk 1972) have led researchers to conclude that these taxa are closely related. Additionally, a hybridization study indicated that geography, and not mating incompatibility, is responsible for the taxonomic separation within the group (Hawley and Dehayes 1985b). The taxa appear to exhibit clinal variation in two directions: from west to east between subalpine fir and balsam fir (Hunt and von Rudloff 1974; Parker et al. 1981; Parker et al. 1984), and from north to south between balsam fir and Fraser fir (Robinson and Thor 1969; Zavarin and Snajberk 1972; Thor and Barnett 1974). Several studies have found strong similarities between balsam fir and Fraser fir, in cone and needle morphology (Myers and Bormann 1963; Robinson and Thor 1969), resin chemistry (Zavarin and Snajberk 1972; Thor and Barnett 1974), and seed proteins (Clarkson and Fairbrothers 1970; Jacobs et al. 1984). These similarities led Thor and Barnett (1974) to consider Fraser fir a variety of balsam fir. Fraser fir and balsam fir may have had relatively unrestricted gene exchange as recently as 10,000 years ago, and exhibit the amount of variability that might be expected within a single species (Jacobs et al. 1984). One set of researchers, however, considered them genetically differentiated enough, based on chloroplast DNA markers, to justify recognition of Fraser fir as a distinct management unit for conservation purposes (Clark et al. 2000).

The intermediary cone morphology of intermediate fir, between the well-exserted and strongly reflexed cone bracts of Fraser fir and the non-exserted bracts of balsam fir (Bakuzis and Hansen 1965; Liu 1971), underscores the clinal morphological variation within this species complex. In addition to the high-elevation intermediate fir stands in Virginia and West Virginia (Mazzeo 1966; Stephenson and Adams 1986), firs with slightly exserted bracts also occur sporadically further to the north in parts of the range of balsam fir, including in the high elevations of the northern Appalachians, along the coast of the Maritime Provinces in Canada, and in the St. Lawrence River valley (Myers and Bormann 1963; Lester 1968). This intermediate form has been described as a separate species, Abies intermedia Full., but that classification has been widely rejected (Robinson and Thor 1969; Clarkson and Fairbrothers 1970; Jacobs et al. 1984). Other authors (Core 1934; Fulling
1936; Liu 1971; Farjon and Rushforth 1989) have hypothesized that intermediate fir $(A . \times$ phanerolepis [Fernald] Liu) was created by the hybridization of Fraser fir and balsam fir when the two previously existing species briefly became sympatric during the Pleistocene. While balsam and Fraser fir are crossable (Klaehn and Winieski 1962; Hawley and Dehayes 1985b; Hawley and Dehayes 1985a), researchers have rejected the hybrid origin of intermediate fir, based on protein electrophoretic banding patterns (Clarkson and Fairbrothers 1970); hybrid indices of morphological traits (Robinson and Thor 1969; Thor and Barnett 1974); and the clustering pattern of Fraser, balsam and intermediate fir populations in an allozyme study (Jacobs et al. 1984).

The recent evolutionary history of the North American balsam firs, including their refugia during one or more Quaternary glacial peaks, may have played an important role in creating the differences now observed among them. Specifically, the present relationships among Fraser, intermediate and balsam fir may result from a long history of Pleistocene climatic fluctuations that repeatedly splintered and reamalgamated Abies populations (Jacobs et al. 1984).

The current study employed ten microsatellite molecular markers developed from Fraser fir (Josserand et al. 2006) to test three hypotheses: (1) that the two fir taxa of the southeastern United States, Fraser fir and intermediate fir, are differentiated enough to retain their classification as belonging to separate species; (2) that cryptic genetic variation exists within these taxa as a result of their disjunct population structure; and (3) that the Quaternary biogeographical history of these taxa is reflected in their relationship to balsam fir. Exploring the genetic relationships among Fraser fir, intermediate fir and balsam fir should offer insights into population genetic and speciation processes in boreal conifers, and should help clarify how this North American species complex responded to the dramatic distributional shifts caused by long-term climate changes. The results may also prove important for in situ and ex situ gene conservation efforts for these two taxa, which are imperiled by an exotic insect and potentially by the effects of climate change. Fraser fir has experienced severe mortality across much of its range as a result of infestation by the balsam woolly adelgid (Adelges piceae [Ratz.]), an insect from Eurasia (Dull et al. 1988), while intermediate fir stands in West Virginia have become infested more recently (Bross-Fregonara 2002). Fraser fir is listed as an imperiled (G2) globally, as critically imperiled in Virginia and Tennessee (S1), and as imperiled in North Carolina (S2) (NatureServe 2009). Intermediate fir is listed as critically imperiled in Virginia (S1) (Townsend 2009) and vulnerable in West Virginia (S3) (West Virginia Natural Heritage Program 2003). 


\section{Materials and methods}

Sample collection and DNA extraction

This analysis encompassed foliage samples from a total of 225 trees representing the Abies section Balsamea Englm. taxa of North America: 80 from four populations of Fraser fir (A. fraseri); 61 from five intermediate fir (A. balsamea var. phanerolepis) sites in West Virginia and Virginia; 74 from individual balsam fir (Abies balsamea var. balsamea) trees, collected from across the distribution of the species; and 10 from subalpine fir (A. lasiocarpa), which was included as an outgroup (Table 1; Fig. 1). The intermediate fir samples from Virginia were collected from Stoney Man Mountain and Hawksbill Mountain in Shenandoah National Park, and combined into a single population because of the small sample size of each. All of the Fraser and intermediate fir samples were taken from mature trees, as were 38 of the balsam fir samples. The other 36 balsam fir samples, and most of the subalpine fir samples, were grown from seed provided by the National Tree Seed Centre of Natural Resources Canada (see Appendix Table 6 for origin of each balsam fir sample). This combination of mature trees and seedlings was necessary to adequately represent the extent of balsam fir across its wide natural range. We later compared microsatellite population genetics statistics for seedlings and mature trees, controlling for longitude, to assess whether these results were affected by life stage, as has been the case using allozyme markers (Bush and Smouse 1992). There was no significant difference in inbreeding between the mature trees and seedlings ( $F_{I S}$ of 0.432 and 0.319 , respectively), according to a $t$-test. The two groups were not genetically differentiated $\left(F_{S T}\right.$ was not significantly different from 0$)$ and had similar numbers of alleles sampled (4.9 and 5.1) and allelic richness (4.2 and 4.1). Based on these results, we included samples from both mature trees and seedlings.

Genomic DNA for all samples was extracted from the needle samples using the DNeasy Plant Mini Kit (Qiagen, Chatsworth, California, USA). DNA concentrations were estimated using known concentrations of $\lambda$ DNA on $1.5 \%$ agarose gels, and were standardized at approximately 7.5$10 \mathrm{ng} / \mu \mathrm{l}$.

\section{Microsatellite analysis}

The 10 microsatellite loci included in this study were isolated from a Fraser fir genomic library enriched for DNA sequences containing tandem di- and tri-nucleotide repeats (Josserand et al. 2006). Polymerase chain reaction (PCR) amplification was performed in $12-\mu \mathrm{l}$ reaction volumes containing $10 \mathrm{ng}$ genomic DNA, $1.25 \mu \mathrm{M}$ of each forward and reverse primer, $0.625 \mathrm{mM}$ dNTPs, $1 \times$ Taq buffer $(2.0 \mathrm{mM} \mathrm{MgCl} 2,10 \mathrm{mM}$ Tris-Cl, $50 \mathrm{mM} \mathrm{KCl}), 120 \mathrm{mM}$ $\mathrm{MgCl}_{2}$, and $0.5 \mathrm{U}$ "hot start" Platinum Taq DNA polymerase (Invitrogen Corp., Carlsbad, California, USA). The

Table 1 Location, sample size, coordinates, elevation, and source for the samples included in the microsatellite analysis of Fraser fir, intermediate fir, and balsam fir, with subalpine fir as an outgroup

\begin{tabular}{|c|c|c|c|c|c|}
\hline Population & Source & $n$ & Longitude & Latitude & Elev. (m) \\
\hline \multicolumn{6}{|l|}{ Fraser fir $(N=80)$} \\
\hline Mount Rogers & Virginia $^{\mathrm{a}}$ & 20 & -83.00 & 35.37 & 1,780 \\
\hline Roan Mountain & North Carolina/Tennessee ${ }^{a}$ & 20 & -82.28 & 35.73 & 1,707 \\
\hline Balsam Mountains & North Carolina $^{\mathrm{a}}$ & 20 & -81.82 & 36.10 & 1,615 \\
\hline Great Smoky Mountains & North Carolina/Tennessee ${ }^{a}$ & 20 & -83.50 & 35.56 & 1,975 \\
\hline \multicolumn{6}{|l|}{ Intermediate fir $(N=61)$} \\
\hline Canaan Valley & West Virginia $^{\mathrm{b}, \mathrm{c}}$ & 20 & -79.46 & 39.03 & 985 \\
\hline Stonecoal Run & West Virginia $^{c}$ & 10 & -79.38 & 39.02 & 1,119 \\
\hline Blister Swamp & West Virginia $^{c}$ & 9 & -79.67 & 38.68 & 1,106 \\
\hline Cheat Mountain/Blister Run & West Virginia ${ }^{\mathrm{b}, \mathrm{c}}$ & 14 & -79.90 & 38.62 & 1,116 \\
\hline Shenandoah National Park & Virginia $^{c}$ & 8 & -78.40 & 38.55 & 1,206 \\
\hline \multicolumn{6}{|l|}{ Balsam fir $(N=74)$} \\
\hline Maritime & Canada/northern U.S. ${ }^{\mathrm{d}}$ & 42 & $-67.91^{\mathrm{e}}$ & $46.20^{\mathrm{e}}$ & $248^{\mathrm{e}}$ \\
\hline Central & Canada/northern U.S. ${ }^{\mathrm{d}}$ & 13 & $-75.14^{\mathrm{e}}$ & $45.89^{\mathrm{e}}$ & $420^{\mathrm{e}}$ \\
\hline Western & Canada/northern U.S. ${ }^{\mathrm{d}}$ & 19 & $-81.85^{\mathrm{e}}$ & $47.17^{\mathrm{e}}$ & $400^{\mathrm{e}}$ \\
\hline \multicolumn{6}{|l|}{ Subalpine fir $(N=10)$} \\
\hline Subalpine fir & Western North America ${ }^{\mathrm{d}}$ & 10 & $-118.60^{\mathrm{e}}$ & $49.30^{\mathrm{e}}$ & $1585^{\mathrm{e}}$ \\
\hline
\end{tabular}

Collection notes: ${ }^{\mathrm{a}}$ K.M. Potter; ${ }^{\mathrm{b}}$ C.M. Clark; ${ }^{\mathrm{c}}$ Ohio State University; ${ }^{\mathrm{d}}$ Collection of single trees from multiple locations; see Appendix Table 6 for details. ${ }^{\mathrm{e}}$ Mean from multiple single-tree collection sites 


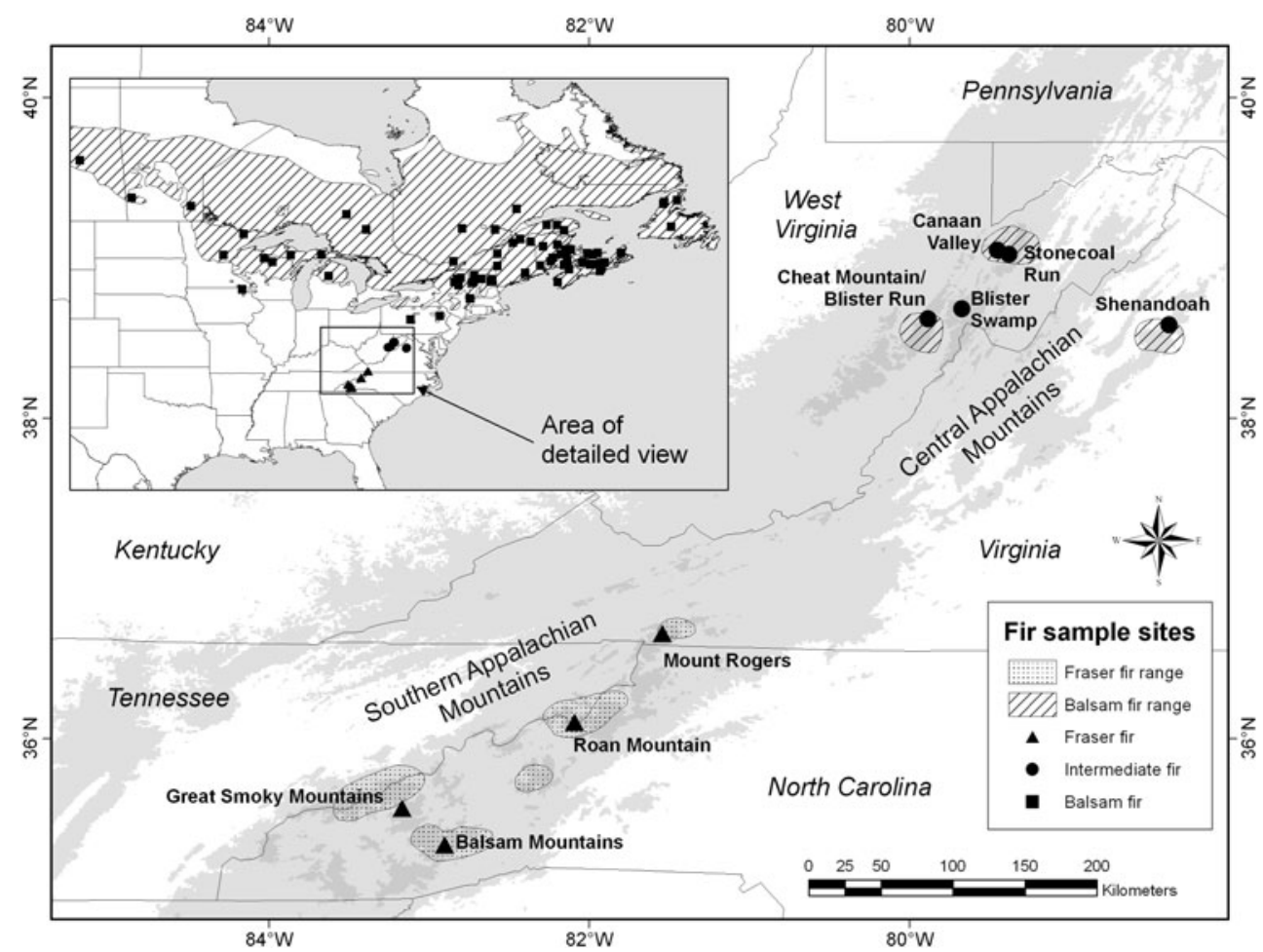

Fig. 1 Sample locations of Fraser fir (Abies fraseri), intermediate fir (A. balsamea var. phanerolepis) and balsam fir (A. balsamea var. balsamea)

PCRs were completed using the following touchdown protocol on PTC-100 thermal cyclers (MJ Research, Watertown, Massachusetts, USA): 2 min at $94^{\circ} \mathrm{C}$; followed by 20 cycles of $30 \mathrm{~s}$ at $94^{\circ} \mathrm{C}, 30 \mathrm{~s}$ at $X$, and $30 \mathrm{~s}$ at $72^{\circ} \mathrm{C}$ where $X=65^{\circ} \mathrm{C}$ in the first cycle decreasing by $0.5^{\circ} \mathrm{C}$ every cycle thereafter; followed by 15 cycles of $30 \mathrm{~s}$ at $92^{\circ} \mathrm{C}, 30 \mathrm{~s}$ at $55^{\circ} \mathrm{C}, 1 \mathrm{~min}$ at $72^{\circ} \mathrm{C}$; followed by a $15 \mathrm{~min}$ extension at $72^{\circ} \mathrm{C}$ and an indefinite hold at $4^{\circ} \mathrm{C}$. The resulting PCR products were purified using Performa DTR V3 96-Well Short Plates (Edge BioSystems, Gaithersburg, Maryland, USA) and were separated on an ABI 3700 Genetic Analyzer (Applied Biosystems, Foster City, California, USA) as recommended by the manufacturer. The Genotyper software package (Applied Biosystems, Foster City, California, USA) was used to size the peaks in base pairs and to score alleles, with GS(500-250)LIZ as an internal size standard.

\section{Data analyses}

Weir and Cockerham (1984) within-population inbreeding coefficient $\left(F_{I S}\right)$ values were calculated across loci using FSTAT v. 2.9.3.2 (Goudet 1995). Additionally, FSTAT generated two basic population-level measures of genetic diversity, allelic diversity $(A)$ and mean allelic richness $\left(A_{R}\right)$, and it estimated among-population divergence $\left(F_{S T}\right)$ within taxa, as well as pairwise $F_{S T}$ of taxa and of genetic clusters inferred using the InStruct package (see below).
The Genetic Data Analysis (GDA) package (Lewis and Zaykin 2001) was used to calculate observed heterozygosity $\left(H_{O}\right)$ values and private alleles for taxa and populations. Exact tests for Hardy-Weinberg equilibrium for each locus, taxon and population were conducted with Genepop (Raymond and Rousset 1995). Genepop also used the private allele method (Barton and Slatkin 1986) to estimate inter-population gene flow $(\mathrm{Nm})$ within taxa, between pairs of taxa, and between pairs of genetic clusters. Micro-Checker 2.2.3 (van Oosterhout et al. 2004) estimated null allele frequencies for each locus, based on Brookfield (1996).

The Bayesian clustering program InStruct (Gao et al. 2007) was used to identify population structure within taxa: Fraser fir, intermediate fir and balsam fir. As an extension of the popular Bayesian clustering program STRUCTURE (Pritchard et al. 2000), InStruct eliminates the assumption of Hardy-Weinberg equilibrium within clusters (Gao et al. 2007). This approach was necessary because of the high level of inbreeding and lack of Hardy-Weinberg equilibrium detected in the current study and in a separate study of Fraser fir using the same microsatellite markers (Potter et al. 2008). Bayesian approaches such as STRUCTURE and InStruct, which pool sets of individuals independently of their sample structure, have the advantage of combining information from several loci into a single probability model, rather than simply averaging across loci as required in traditional $F_{S T}$ analysis (Corander et al. 2003). Structure 
detected within taxa can reveal information about the ancestry of groups of individuals, with the presence of genetic clusters reflecting the existence of groups of individuals that have become relatively isolated from each other as a result of restricted migration and reproduction patterns (Corander et al. 2008).

Three Markov chain Monte Carlo (MCMC) runs were completed for each taxon using InStruct, with the program making inferences about the optimal number of genetic clusters $(K)$ for each using deviance information criteria (Gao et al. 2007). The range of genetic clusters tested was $K=1$ to $K=4$ for Fraser fir, $K=1$ to $K=6$ for intermediate fir, and $K=1$ to $K=10$ for balsam fir. The burnin was set to 100,000 replicates, and the Markov chain Monte Carlo to 200,000 iterations, which were the default settings for the program. For Fraser fir and intermediate fir, geographical populations were assigned to membership in inferred genetic clusters based on the percent of each genetic cluster present in the population. Because balsam fir was sampled individually across its range, each individual sample was assigned to a genetic cluster in a similar manner. A separate InStruct analysis used all the samples in the study to quantify genetic admixture among the genetic clusters previously determined by the initial InStruct analysis, testing from $K=4$ to $K=10$.

A neighbor-joining (NJ) phylogenetic tree was constructed using the SEQBOOT, GENDIST, NEIGHBOR, and CONSENSE components of PHYLIP 3.6 (Felsenstein 2005) to visualize potential evolutionary relationships among the genetic clusters. Confidence estimates associated with the topology of the tree were determined with 1,000 bootstrap replicates. The tree was generated using chord genetic distance $\left(D_{C}\right)$ (Cavalli-Sforza and Edwards 1967) based on population allelic frequencies, because this distance measure is considered superior to most others in phylogenetic tree topology construction over short spans of evolutionary time (Takezaki and Nei 1996). Additionally, $D_{C}$ is based on a geometric model that is less biased by null alleles than other genetic distances in microsatellite analyses (Chapuis and Estoup 2007), and which does not require assumptions about the model under which microsatellites mutate (Takezaki and Nei 1996). Subalpine fir was included in the tree as an outgroup. PHYLIP 3.6 (Felsenstein 2005) was also employed to estimate $D_{C}$ genetic distance between the taxa included in the study (balsam fir, intermediate fir, Fraser fir and subalpine fir), and between the genetic clusters determined using InStruct.

\section{Results}

The average number of alleles observed across the 10 microsatellite loci and 215 ingroup trees was 10.3 (ranging
Table 2 Description of the 10 microsatellite loci used in the study (from Josserand et al. 2006) and measures of genetic variation, inbreeding, deviation from Hardy-Weinberg equilibrium, and estimated null allele frequency for each

\begin{tabular}{lrlllll}
\hline Locus & \multicolumn{1}{c}{$A$} & $H_{E}$ & $H_{O}$ & $F_{I S}$ & HWE & Prop. null \\
\hline AfSI03 & 4 & 0.456 & 0.425 & 0.069 & $* *$ & 0.021 \\
AfSI04 & 3 & 0.335 & 0.126 & 0.616 & $* * * *$ & 0.154 \\
AfSI05 & 11 & 0.720 & 0.404 & 0.434 & $* * * *$ & 0.181 \\
AfSI06 & 19 & 0.880 & 0.770 & 0.125 & $* * *$ & 0.058 \\
AfSI08 & 16 & 0.698 & 0.443 & 0.364 & $* * * *$ & 0.149 \\
AfSI09 & 11 & 0.296 & 0.142 & 0.517 & $* * * *$ & 0.119 \\
AfSI11 & 7 & 0.172 & 0.144 & 0.160 & ns & 0.023 \\
AfSI14 & 16 & 0.473 & 0.189 & 0.601 & $* * * *$ & 0.191 \\
AfSI16 & 11 & 0.712 & 0.391 & 0.453 & $* * * *$ & 0.188 \\
AfSI20 & 5 & 0.145 & 0.121 & 0.159 & $* * *$ & 0.020 \\
Mean & 10.3 & 0.489 & 0.316 & 0.353 & $* * * *$ & 0.110 \\
\hline
\end{tabular}

Results exclude outgroup species; $A$ alleles per locus, $H_{E}$ expected heterozygosity, $H_{o}$ observed heterozygosity, $F_{I S}$ inbreeding coefficient, $H W E$ Hardy-Weinberg exact test of heterozygote deficiency, with $* * p<0.01$, *** $p<0.001$, *** $p<0.0001$; Prop. null: estimated proportion of null alleles (Brookfield 1996)

from 3 to 19), with all but one of the loci out of HardyWeinberg equilibrium (Table 2). The consistently significant deficiency of heterozygotes and the consistently positive inbreeding coefficient $F_{I S}$ across loci and taxa (Tables 2, 3) suggests a biological explanation such as inbreeding for this lack of HWE, rather than an overriding effect of null alleles (Amos 2006).

InStruct (Gao et al. 2007) inferred the existence of two Fraser fir genetic clusters, three intermediate fir clusters, and three balsam fir clusters (Table 3), based on the lowest deviance information criteria from three MCMC runs completed for each range of $K$ for each taxon. Within Fraser fir, the Mount Rogers population, which is the most isolated and northern of the populations, was assigned to a genetic cluster by itself ("northern Fraser fir," NFF), while the other three populations were grouped together into a single genetic cluster ("southern Fraser fir," SFF). Within intermediate fir, two populations were assigned to individual genetic clusters, the Shenandoah National Park population ("Virginia intermediate fir," VIF) and the southernmost population in West Virginia at Cheat Mountain/Blister Run ("southern intermediate fir," SIF). The rest of the intermediate fir populations were assigned to a single genetic cluster ("northern intermediate fir," NIF).

Each balsam fir individual sample was assigned to one of the three clusters determined for the species using InStruct (see the Appendix Table 6 for each sample's assignment). After ArcMap 9.2 (ESRI 2006) was used to calculate the mean latitude and longitude coordinates for the balsam fir trees belonging to each of the genetic clusters 
Table 3 Measures of genetic variation in populations of Fraser fir and intermediate fir, and genetic clusters of balsam fir, based on 10 nuclear microsatellite loci

\begin{tabular}{|c|c|c|c|c|c|c|c|c|c|c|c|c|}
\hline Taxon/population & $n$ & $A$ & $A_{R}$ & $A P_{\operatorname{tax}}$ & $A P_{\text {all }}$ & $P$ & $H_{O}$ & $F_{I S}$ & HWE & $F_{S T}$ & $\mathrm{Nm}$ & Cluster \\
\hline Fraser fir & 80 & 6.2 & 2.7 & - & 6 & 100 & 0.308 & 0.235 & $* * * *$ & 0.025 & 6.65 & - \\
\hline Mount Rogers (RGS) & 20 & 3.9 & 2.7 & 6 & 2 & 100 & 0.325 & 0.178 & $* * * *$ & - & - & NFF \\
\hline Roan Mountain (ROAN) & 20 & 3.6 & 2.6 & 0 & 0 & 90 & 0.283 & 0.262 & $* * * *$ & - & - & SFF \\
\hline Balsam Mountains (BLM) & 20 & 4.1 & 2.6 & 5 & 4 & 90 & 0.296 & 0.205 & $* * *$ & - & - & SFF \\
\hline Great Smoky Mountains (GSM) & 20 & 4.2 & 2.8 & 6 & 0 & 100 & 0.339 & 0.207 & $* * * *$ & - & - & SFF \\
\hline Intermediate fir & 61 & 6.4 & 3.2 & - & 2 & 90 & 0.303 & 0.358 & $* * * *$ & 0.140 & 0.71 & - \\
\hline Canaan Valley (CAN) & 20 & 4.3 & 2.8 & 9 & 1 & 90 & 0.309 & 0.293 & $* * * *$ & - & - & NIF \\
\hline Stonecoal Run (SCR) & 10 & 3.0 & 2.6 & 3 & 0 & 90 & 0.322 & 0.242 & $*$ & - & - & NIF \\
\hline Blister Swamp (BLS) & 9 & 3.0 & 2.7 & 4 & 1 & 90 & 0.269 & 0.369 & $* * *$ & - & - & NIF \\
\hline Cheat Mountain/Blister Run (CHT) & 14 & 3.1 & 2.5 & 4 & 0 & 70 & 0.314 & 0.218 & $* *$ & - & - & SIF \\
\hline Shenandoah National Park (SHN) & 8 & 2.5 & 2.4 & 3 & 0 & 80 & 0.262 & 0.338 & $* *$ & - & - & VIF \\
\hline Balsam fir & 74 & 8.6 & 3.7 & - & 15 & 100 & 0.343 & 0.391 & $* * * *$ & 0.133 & 2.25 & - \\
\hline Maritime cluster (MBF) & 42 & 6.1 & 4.2 & 15 & 8 & 100 & 0.304 & 0.367 & $* * * *$ & - & - & $\mathrm{MBF}$ \\
\hline Central cluster (CBF) & 13 & 5.3 & 5.1 & 11 & 4 & 100 & 0.440 & 0.292 & $* * * *$ & - & - & $\mathrm{CBF}$ \\
\hline Western cluster (WBF) & 19 & 5.3 & 4.5 & 11 & 3 & 100 & 0.362 & 0.311 & $* * * *$ & - & - & WBF \\
\hline Subalpine fir & 10 & 4.4 & 3.6 & - & 9 & 80 & 0.387 & 0.313 & $* * * *$ & - & - & SAF \\
\hline
\end{tabular}

Notes: $A$ mean alleles per locus, $A_{R}$ mean allelic richness, $A P$ private (unique) alleles, within taxa $\left(A P_{\text {tax }}\right)$ and across taxa $\left(A P_{\text {all }}\right), P$ percentage of polymorphism, using $99 \%$ criterion, $H_{O}$ observed heterozygosity, $F_{I S}$ mean fixation index, $H W E$ Hardy-Weinberg exact test of heterozygote deficiency, with $* p<0.05$, ** $p<0.01$, *** $p<0.001, * * * * p<0.0001, F_{S T}$ within-taxon genetic differentiation, $N m$ estimated gene-flow within taxon, Cluster Cluster assignment following Bayesian clustering analysis in InStruct, NFF northern Fraser fir, $S F F$ southern Fraser fir, NIF northern intermediate fir, SIF southern intermediate fir, VIF Virginia intermediate fir, $M B F$ maritime balsam fir, $C B F$ central balsam fir, $W B F$ western balsam fir, $S A F$ subalpine fir

(Table 1), one cluster was centered in the Maritime provinces of Canada ("Maritime balsam fir," MBF), one was centered in southern Quebec, eastern Ontario and northern New York ("central balsam fir," CBF), and one was centered in the Great Lakes region ("western balsam fir," WBF).

When all the samples were tested in InStruct (Gao et al. 2007) for admixture, the program detected the lowest deviance information criterion at $K=6$, or six separate gene pools (Fig. 2). The proportion of each gene pool contained within the two Fraser fir genetic clusters (NFF and SFF) was highly similar, with gene pool 6 dominating. This gene pool was also common in the ancestry of the northern (NIF) and southern (SIF) intermediate fir clusters and in the Maritime balsam fir (MBF) cluster but greatly decreased in the central $(\mathrm{CBF})$ and western $(\mathrm{WBF})$ clusters. Among the balsam fir clusters, a clear pattern of east-towest clinal increase was apparent for gene pools 4 and 6 , while a pattern of west-to-east clinal increase existed for gene pools 2 and 5. The Virginia intermediate fir cluster (VIF) was similar to the western balsam fir (WBF) cluster but had little in common with the nearby intermediate fir clusters in West Virginia. In fact, six of these eight trees consist mostly of predicted ancestry from gene pool 5, the predominant gene pool of WBF, while the other two samples contain almost no predicted ancestry from that gene pool, instead containing mostly ancestry from gene pools 4 and 6 , similar to the composition of the other intermediate fir genetic clusters.

\section{Microsatellite variation}

At the taxon level, the amount of differentiation among Fraser fir, intermediate fir and balsam fir was relatively low, with a mean $F_{S T}$ of 0.057 ; bootstrapped across loci, this value was statistically different from 0 at $p<0.05$. When subalpine fir was added to the analysis, the mean $F_{S T}$ increased to 0.091, again different from 0 . The same analysis, comparing inferred genetic clusters rather than taxa, found a greater level of differentiation: $F_{S T}$ of 0.115 with subalpine fir excluded and 0.138 with it included. Interestingly, the mean $F_{S T}$ was high when testing the differentiation among the five intermediate fir populations $\left(F_{S T}=0.140\right.$ with all populations, $F_{S T}=0.086$ when the Shenandoah National Park population was excluded), compared to $F_{S T}=0.025$ among the four Fraser fir populations. The Fraser fir populations had the highest estimated inter-population gene flow $(\mathrm{Nm})$, with an estimated 6.65 migrants per generation, while intermediate fir had the lowest $\mathrm{Nm}$ of 0.71 (Table 3). 


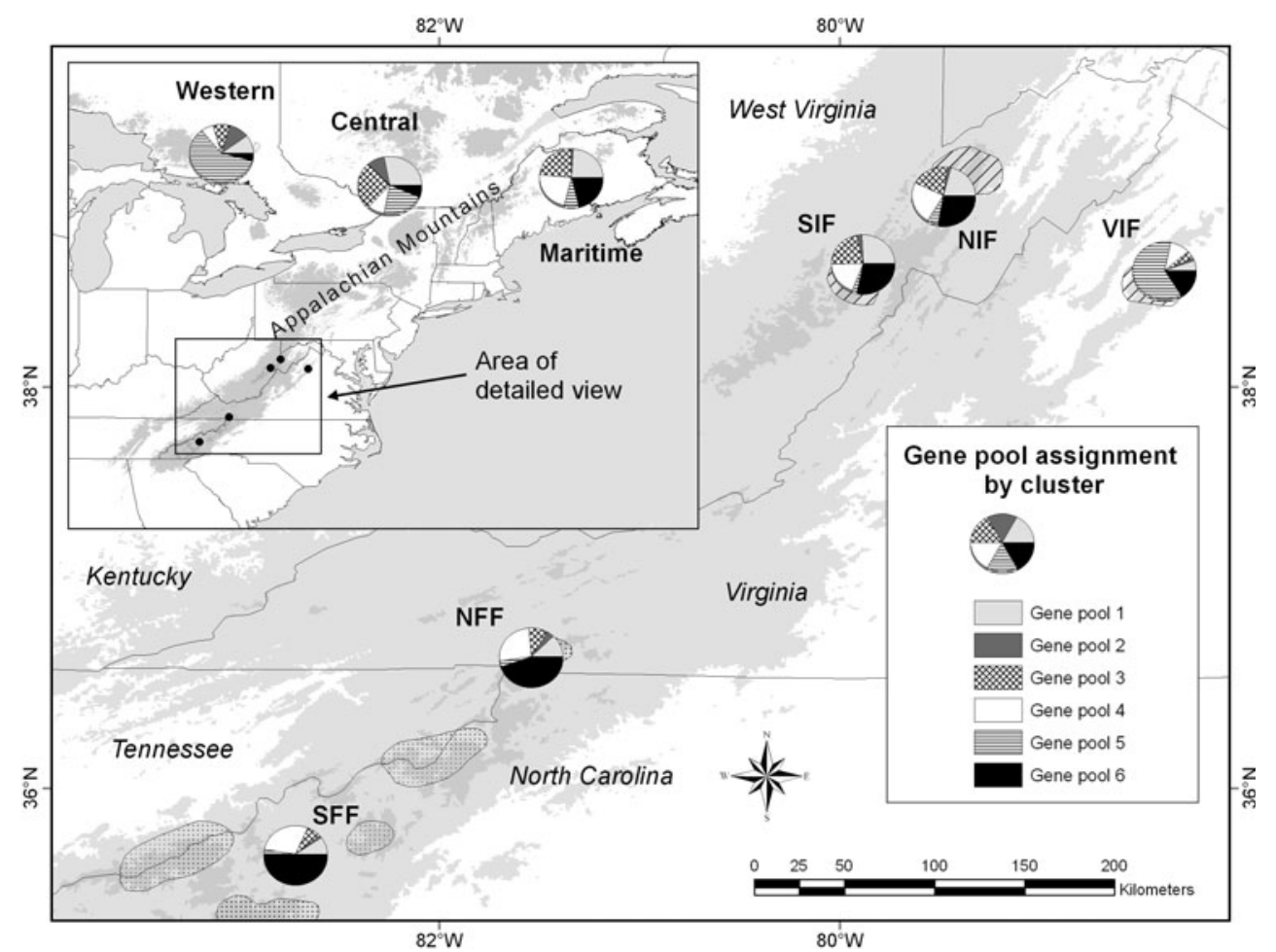

Fig. 2 The estimated proportion of inferred ancestry for each Fraser fir, intermediate fir, and balsam fir genetic cluster defined using InStruct (Gao et al. 2007). See Table 3 for cluster abbreviations

Genetic variation within taxa and populations

Despite a sample size similar to Fraser fir and intermediate fir, balsam fir had greater genetic diversity than those taxa by several measures (Table 3 ), including alleles per locus $(A)$, allelic richness $\left(A_{R}\right)$, number of private alleles across taxa $\left(A P_{\text {all }}\right)$, and observed homozogosity $\left(H_{o}\right)$. Fraser fir had the lowest values for most of these measures.

Among the Fraser fir populations, Mount Rogers, the most isolated and northernmost population, and the Balsam Mountains, the southernmost population, had the most overall private alleles ( $A P_{\text {all }}$ ) (Table 3$)$. Meanwhile, Mount Rogers and the Great Smoky Mountains, the largest population, had the most private alleles within the Fraser fir taxon $\left(A P_{\text {tax }}\right)$ and the highest values of $A_{R}, P$, and $H_{o}$. Among the intermediate fir populations, only Canaan Valley and Blister Swamp had overall private alleles, while Canaan Valley had by far the most private alleles within the taxon. Within balsam fir, the Maritime genetic cluster had the highest values of $A, A P_{\text {tax }}$, and $A P_{\text {all }}$, which is perhaps not surprising given the larger size of this genetic cluster. More surprisingly, the central genetic cluster had higher $A_{R}$ and $H_{o}$, despite a smaller sample size.
Genetic structure and differentiation

Pairwise measures of genetic differentiation among the study taxa $\left(D_{C}\right.$ genetic distance and $\left.F_{S T}\right)$ indicate that intermediate fir is, in fact, genetically intermediate between balsam fir and Fraser fir, if slightly more closely related to balsam fir (Table 4). The pairwise $F_{S T}$ measures between balsam fir and intermediate fir (0.029), and between intermediate fir and Fraser fir (0.039), were both statistically significant but small. Pairwise patterns of genetic differentiation and estimates of historical migration $(\mathrm{Nm})$ (Table 5) suggest close genetic relationships among the genetic clusters of Fraser fir and intermediate fir, and the

Table 4 Pairwise comparisons among taxa of North American balsam fir based on 10 polymorphic microsatellite loci

\begin{tabular}{lllll}
\hline Taxon & Balsam fir & Intermediate fir & Fraser fir & Subalpine fir \\
\hline Balsam fir & & 0.026 & 0.058 & 0.126 \\
Intermediate fir & 0.029 & & 0.034 & 0.130 \\
Fraser fir & 0.094 & 0.039 & & 0.147 \\
Subalpine fir & 0.188 & 0.254 & 0.334 & \\
\hline
\end{tabular}

Upper diagonal: chord $\left(D_{C}\right)$ genetic distance (Cavalli-Sforza and Edwards 1967); lower diagonal: cluster pairwise $F_{S T}$, with all values significantly different from 0 at $p=0.05$ 
Table 5 Pairwise comparisons among populations of North American balsam fir based on 10 polymorphic microsatellite loci

\begin{tabular}{|c|c|c|c|c|c|c|c|c|c|}
\hline \multirow[t]{2}{*}{ Population } & \multicolumn{3}{|c|}{ Balsam fir } & \multicolumn{3}{|c|}{ Intermediate fir } & \multicolumn{2}{|c|}{ Fraser fir } & \multirow[t]{2}{*}{ Subalpine fir (SAF) } \\
\hline & $\mathrm{MBF}$ & $\mathrm{CBF}$ & WBF & NIF & SIF & VIF & NFF & SFF & \\
\hline $\mathrm{MBF}$ & & 1.74 & 2.25 & 2.85 & 1.83 & 1.11 & 1.57 & 1.78 & 0.72 \\
\hline $\mathrm{CBF}$ & 0.096 & & 2.06 & 0.98 & 0.95 & 1.18 & 0.74 & 0.66 & 1.15 \\
\hline WBF & 0.181 & 0.058 & & 1.47 & 0.73 & 0.90 & 0.74 & 0.66 & 0.81 \\
\hline NIF & 0.040 & 0.119 & 0.175 & & 1.24 & 1.01 & 2.33 & 2.28 & 0.85 \\
\hline SIF & 0.110 & 0.122 & 0.231 & 0.093 & & 0.28 & 1.09 & 1.12 & 0.54 \\
\hline VIF & 0.158 & 0.113 & 0.150 & 0.204 & 0.275 & & 0.75 & 1.65 & 0.44 \\
\hline NFF & 0.081 & 0.151 & 0.222 & 0.050 & 0.068 & 0.219 & & 4.12 & 0.48 \\
\hline SFF & 0.079 & 0.181 & 0.254 & 0.058 & 0.068 & 0.225 & 0.001 & & 0.39 \\
\hline SAF & 0.285 & 0.133 & 0.156 & 0.287 & 0.276 & 0.264 & 0.318 & 0.335 & \\
\hline
\end{tabular}

Upper diagonal: estimated of number of migrants per generation $(\mathrm{Nm})$ using the private allele method; lower diagonal: cluster pairwise $F_{S T}$, with italicized values significantly different from 0 at $p=0.05$

Maritime genetic cluster of balsam fir (MBF). For example, the pairwise $F_{S T}$ values between the Fraser fir and West Virginia intermediate fir genetic clusters were generally small, with the pairwise $F_{S T}$ between the northern Fraser fir (NFF) and northern intermediate fir (NIF) genetic clusters not significantly different from 0 . The estimated effective number of migrants $(\mathrm{Nm})$ between the Fraser fir clusters and the NIF cluster were also high, suggesting at least some historical connection between these groups. The MBF cluster is apparently the most closely related of the balsam fir clusters to both intermediate fir and Fraser fir, with a pairwise $F_{S T}$ of only 0.040 with the NIF cluster and of 0.080 and 0.079 with the NFF and SFF clusters, respectively. In fact, the genetic differentiation between the MBF cluster and these intermediate and Fraser fir clusters is lower than its differentiation from the other balsam fir clusters, and its genetic distance is lower. The estimated $\mathrm{Nm}$ between $\mathrm{MBF}$ and the intermediate and Fraser fir clusters is also relatively high.

The consensus neighbor-joining dendrogram of $D_{C}$ genetic distance of genetic clusters includes a well-supported clade encompassing the two Fraser fir clusters with the SIF cluster. This clade is in turn grouped with the NIF and MBF clusters (Fig. 3). The VIF is external to this group, with the other two balsam fir clusters grouped separately.

\section{Discussion}

The results of this microsatellite analysis appear to support the proposal by Thor and Barnett (1974) to classify balsam fir, intermediate fir, and Fraser fir as three separate varieties of the same species: Abies balsamea (L.) Mill. var. balsamea, Abies balsamea (L.) Mill. var. phanerolepis Fern., and Abies balsamea (L.) Mill. var. fraseri Spach. Specifically, the low among-taxon $F_{S T}$ of 0.057 suggests

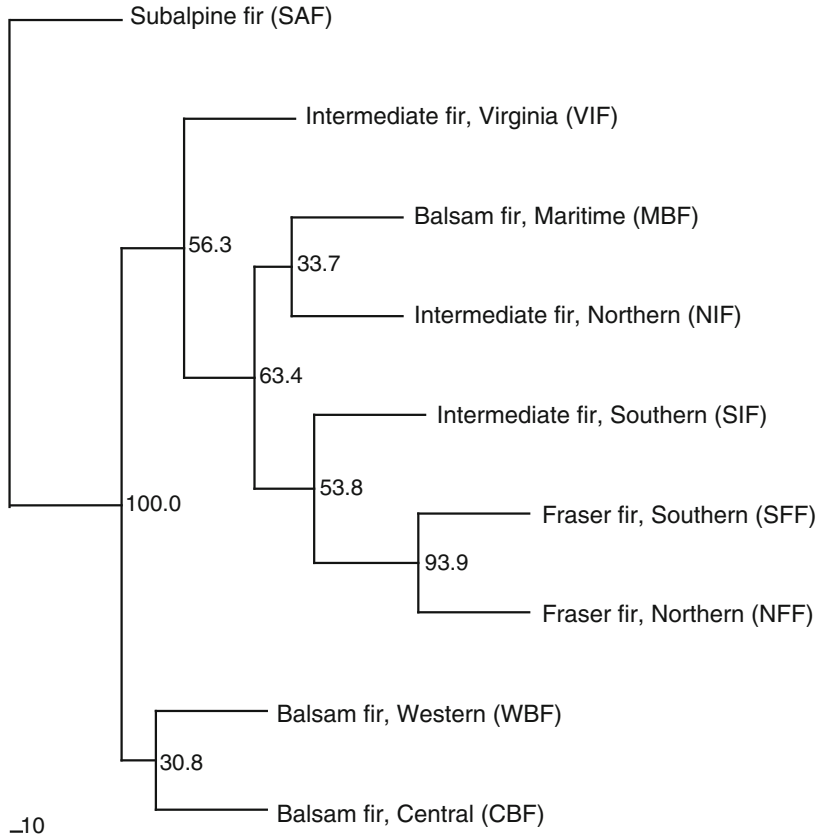

Fig. 3 Consensus neighbor-joining dendrogram depicting $D_{C}$ genetic distance (Cavalli-Sforza and Edwards 1967). The values represent the percent bootstrap support for the nodes over 1,000 replicates

little genetic differentiation among the taxa, a result consistent with that of Clark et al. (2000), who found an $F_{S T}$ of 0.06 among balsam fir, intermediate fir, and Fraser fir using two chloroplast microsatellite loci. Additionally, the current microsatellite results do not indicate clear boundaries among balsam fir, intermediate fir, and Fraser fir. Specifically, intermediate fir was only slightly more closely related to balsam fir than to Fraser fir, and was only slightly less differentiated from Fraser fir than from balsam fir (Table 4). The neighbor-joining dendrogram placed the two Fraser fir genetic clusters in a well-supported clade with the two intermediate fir clades and with the MBF 
cluster, while the other two balsam fir clades were grouped separately (Fig. 3). The MBF cluster, meanwhile, was less differentiated from both of the Fraser fir genetic clusters and from one of the intermediate fir genetic clusters than it was from the CBF and WBF genetic clusters (Table 5). The results, therefore, do not support the treatment of these taxa in a widely accepted sectional classification of the genus Abies (Farjon and Rushforth 1989), which places the taxa in separate subsections within section Balsamea Englm: A. fraseri in subsection Medianae Patschke and $A$. balsamea in subsection Laterales Patschke.

These results further appear to contradict the hypothesis that intermediate fir is of hybrid origin between two comparatively distantly related parental taxa. Little microsatellite differentiation existed among the three taxa, and the neighbor-joining dendrogram placed the Fraser fir genetic clusters in a clade with both intermediate fir and balsam fir genetic clusters (Fig. 3), similar to the results of the isozyme analysis by Jacobs et al. (1984). Had intermediate fir been of hybrid origin between Fraser fir and balsam fir as comparatively distantly related parent species, we might expect populations of each parental species to group together with high bootstrap support. We might also expect populations of intermediate fir to have a slightly stronger affinity to balsam fir than to Fraser fir because they are somewhat more closely related (e.g., Siegismund and Jensen 2001; Lexer et al. 2005). Additionally, intermediate fir, as a hybrid population, should have exhibited increased allelic variation relative to Fraser fir and balsam fir, which was not the case (Table 3). While the results suggest the possibility of historical gene exchange among Fraser fir, intermediate fir and balsam fir (Table 5), they also appear to indicate that Fraser fir and intermediate fir may be relatively recently derived forms of balsam fir that developed along a cline.

The 2-million-year period of cyclical warming and cooling during the Pleistocene Epoch probably greatly influenced the current genetic relationships among these fir taxa, which, like other North American conifers, experienced repeated cycles of migration to and from isolated glacial refuges during that period (Critchfield 1984). During the last (Wisconsinian) glacial period, which began approximately 110,000 years ago and peaked about 20,000 years ago, fir was confined mainly to a narrow band of mixed boreal forest between 34 and $38^{\circ} \mathrm{N}$ stretching from the coast of Virginia and North Carolina into the continental interior (Whitehead 1973; Delcourt and Delcourt 1987). A sudden warming trend, beginning approximately 16,000 years ago, initiated the retreat of the northern continental ice sheet in North America and caused a rapid change in forest vegetation (Davis 1981). By 10,000 years ago, fir populations in the Southern Appalachians were separated from the main distribution of fir, which had shifted north into Canada, New England, and the Northern Appalachians (Delcourt and
Delcourt 1984; Delcourt and Delcourt 1987). All but the highest-elevation stands in the Southern Appalachians were eliminated by the warming temperatures, which peaked during a hypsithermal period about 8,000 years ago, resulting in the currently isolated Fraser and intermediate fir populations (Delcourt and Delcourt 1987).

The results of the current microsatellite study appear to support the Jacobs et al. (1984) hypothesis that Fraser fir was an adaptive extreme of balsam fir during the Wisconsinian glaciation, during which gene exchange between the progenitors of balsam fir and Fraser fir was probably relatively unrestricted. This "montane ecotype model" suggests that, after the main distribution of balsam fir shifted north toward present-day Canada, the genes associated with non-exserted bracts in Fraser fir were lost during the xerothemic period as Fraser fir populations were isolated on mountain tops (Myers and Bormann 1963; Zavarin and Snajberk 1972), while intermediate fir remained a diluted version of the original adaptive extreme (Jacobs et al. 1984). In keeping with this hypothesis, the current microsatellite analyses indicate that, first, the progenitors of Fraser fir, intermediate fir and the MBF genetic cluster may have shared a Pleistocene glacial refuge, given their close relatedness (Table 5; Figs. 2, 3). Second, the Fraser fir and intermediate fir genetic clusters were less genetically diverse by several measures than the $\mathrm{MBF}$ genetic cluster (Table 3 ), which presumably more closely represents the breadth of genetic diversity present in the glacial refuge. This suggests that Fraser and intermediate fir may, as a result of isolation, have lost genes associated with phenotypic traits such as short bract length. Similarly, Clark et al. (2000) found greater chloroplast genetic diversity in balsam fir than in intermediate and Fraser fir, while Zavarin and Snajberk (1972) detected less monoterpene diversity in Fraser fir than in balsam fir.

Further supporting the montane ecotype model is the fact that exserted-bract balsam firs exist along the crest of the northern Appalachians into New England, where they have remained connected to nearby low-elevation populations without exserted bracts (Lester 1968; Zavarin and Snajberk 1972), but where crossing among stands at different elevations has been somewhat hampered by asynchrony in cone phenology or cone production (Neale and Adams 1985). Lester (1968) suggested an association between bract length and precipitation in balsam fir, while recent research has indicated that exserted bracts may play an important role in Abies pollination by assisting in the formation of dew droplets and by funneling water, carrying pollen grains, toward the ovules at the base of the bractscale complexes (Chandler and Owens 2004). Among balsam fir and its close relatives, therefore, exserted bracts may confer a fitness advantage in wetter locations by assisting in pollination, which could explain the persistence 
of this trait in high elevations throughout the Appalachians, along the coast of the Maritime provinces and in the St. Lawrence River valley of Canada (Myers and Bormann 1963; Lester 1968).

Given that the most recent glaciation lasted approximately 100,000 years (Hewitt 1996), the separation of a species into separate refugia would likely result in genetic differentiation that remains detectable after post-warming migration resulted in a more continuous distribution. Several of the results in the current study suggest the existence of at least two separate refuges encompassing balsam fir, intermediate fir and Fraser fir during the last glacial period. One of these may have contained the ancestors of Fraser fir, intermediate fir, and the MBF cluster, which are grouped separately from the two other balsam fir clusters in the $D_{C}$ genetic distance dendrogram (Fig. 3). This and other results (Table 5; Fig. 2) would be consistent with separate refuges to the east and west of the Appalachian highlands, which formed a major barrier between forests to the east and west until about 12,500 years ago (Watts 1979). The fossil record indicates that fir may have migrated northward to the east of the Appalachians more rapidly than on the west (Watts 1979), expanding at a rate of approximately $200 \mathrm{~m}$ per year (Davis 1981). The division of balsam fir to the west of the Appalachians into two genetic clusters (CBF and WBF) is consistent with findings by previous researchers of significant morphological differences between balsam fir trees from east and west of roughly $80^{\circ} \mathrm{W}$. These include differences in cone morphology (Myers and Bormann 1963), growth rates (Lester 1970; Lester et al. 1976; Marty et al. 1983), and monoterpene content (Zavarin and Snajberk 1972; Lester 1974; Reddington and McCormack 1976).

\section{Genetic variation within intermediate fir and Fraser fir}

The extent of genetic differentiation among the intermediate fir populations was unexpected. Particularly interesting was the genetic differentiation between the VIF cluster and the other intermediate fir clusters in West Virginia (Tables 4, 6; Fig. 3). Among the possible contributing factors were the small sample size of the Virginia firs and the different conditions in which the Virginia and West Virginia intermediate firs occur: The West Virginia firs are confined to wet bottomland sites above $975 \mathrm{~m}$, similar to northern swampland forests where balsam fir is often a dominant species (Stephenson and Adams 1986). The Virginia firs, meanwhile, occur in three small stands on the crest of the Blue Ridge Mountains in Shenandoah National Park (Mazzeo 1966). At the same time, the largest share of Virginia intermediate fir inferred genetic ancestry is associated with the predominant gene pool of the WBF cluster (Fig. 3). This, and the placement of the VIF cluster in the dengrogram separately from the West Virginia clusters, suggest the possibility that the transplantation of firs in Shenandoah National Park by the Civilian Conservation Corps in the 1930s (Mazzeo 1966; Roe 1995) may have introduced genetic material from outside the area. These results are intriguing and suggest the need for indepth study of the morphology and population genetics of the Virginia intermediate fir stands.

The six West Virginia intermediate fir stands incorporated in this study represent three of the four populations extant in that state: Canaan Valley, Blister Run, and Blister Swamp (Stephenson and Adams 1986; McDonald 1993). Intermediate fir was most likely a minor component in the red spruce forest that once covered 445,000 ha in this area (Clarkson 1966), but this forest type was almost completely eliminated in the late 1800 s and early 1900 s by poor logging practices and fire (Allard and Leonard 1952). The Blister Run and Cheat Mountain stands together encompass the intermediate fir population with the most stable reproduction and community structure (Stephenson and Adams 1986), but this population is less genetically diverse than the other West Virginia intermediate fir populations by several measures. The results suggest that the Canaan Valley population may be the intermediate fir population that maintained the greatest genetic integrity, with the most alleles per locus, the greatest allelic richness, and the most private alleles (Table 3 ).

Compared to intermediate fir, Fraser fir exhibited very little among-population variation $\left(F_{S T}=0.025\right)$, which is consistent with a recent microsatellite study of Fraser fir seedlings (Potter et al. 2008). As with that study, these results appear to indicate that Fraser fir exists as a genetically well-mixed set of populations, even compared to other long-lived outcrossing gymnosperm species (Hamrick and Godt 1996). The high estimate of inter-population gene flow among Fraser fir populations $(\mathrm{Nm}=6.65)$ would appear to indicate that a considerable amount of amongpopulation gene exchange occurs within Fraser fir, most likely via wind-dispersed pollen movement (Ziegenhagen et al. 2004). The genetic differentiation of Mount Rogers, the most isolated Fraser fir population, was not unexpected, given that previous microsatellite (Potter et al. 2008) and isozyme (Ross 1988) studies have indicated that Mount Rogers is a genetic outlier relative to the rest of the Fraser fir range. It is still apparently more closely related to the other Fraser fir populations than it is to intermediate fir, however (Table 5; Fig. 3).

In addition to clarifying the evolutionary relationships among Fraser fir, intermediate fir, and balsam fir, the results of this study may prove useful for in situ and ex situ gene conservation efforts for Fraser fir and intermediate fir. Both of these taxa are imperiled by the balsam woolly adelgid, an exotic insect from Eurasia which kills mature 
trees within 2-9 years of infestation by causing the trees to produce abnormal xylem that conducts water poorly (Eager 1984; Hollingsworth and Hain 1991). Since the middle of the 20th century, the balsam woolly adelgid has inflicted severe mortality on old-growth Fraser fir, with 67 percent of standing Fraser fir volume dead by the 1980s (Dull et al. 1988). Adelgid-caused mortality also has begun to occur in intermediate fir stands in recent years (Bross-Fregonara 2002). Additionally, both Southeastern fir taxa could face extirpation in the face of global climate change, which poses a particular risk to forest tree species that have limited distributions (Schwartz et al. 2006) and that occur at high elevations (Delcourt and Delcourt 1998).

While the results of the current microsatellite study indicate that Fraser fir is insufficiently differentiated to deserve specific rank, the findings also appear to underscore the existence of evolutionarily significant units (ESUs) within the taxa surveyed. The genetic conservation of these ESUs is important to ensure the recognition and protection of the evolutionary heritage of these units, and to maintain their evolutionary potential (Moritz 1994). The consensus holds that ESUs should encompass both adaptive divergence and historical isolation, since each is functionally important in the accumulation of genetic differences arising by the differential effects of evolutionary forces (Fraser and Bernatchez 2001). We recommend, therefore, that ESUs for the Southeastern fir taxa correspond with the three intermediate fir and two Fraser fir genetic clusters defined using the Bayesian InStruct program (Fig. 2). Each of these clusters is genetically differentiated from the others, presumably as a result at least in part of historical isolation, while obvious morphological adaptive differences exist between the morphology of Fraser fir and intermediate fir (Robinson and Thor 1969; Thor and Barnett 1974). Further differences exist between genetic clusters within each taxon, with different site affinities between the Virginia and West Virginia intermediate fir groups, and with the potential for differences in resistance to balsam woolly adelgid between the northern (Mount Rogers, Virginia) and southern Fraser fir groups (Rheinhardt 1984). To adequately represent the evolutionary diversity of these genetic clusters, and to conserve their potential to evolve into new species, conservation efforts should ensure the collection of an adequate sample of seed from each of these clusters and should emphasize management efforts that maintain the long-term persistence of at least one natural population from each cluster.

Acknowledgments We thank Bernard Daigle of the National Tree Seed Centre at Natural Resources Canada for providing several provenances of balsam fir and subalpine fir; Catherine Clark for sharing her intermediate and balsam fir foliage samples; Jianfeng Li for laboratory help; and Craig Echt and two anonymous reviewers for their thoughtful comments on the manuscript. This work was supported by the College of Natural Resources, the Christmas Tree Genetics Program, the Department of Forestry and Environmental Resources, and the Graduate School at North Carolina State University. It also was supported in part through Research Joint Venture Agreement 08-JV-11330146-078 between the U.S. Department of Agriculture, Forest Service, Southern Research Station, and North Carolina State University.

\section{Appendix}

See Table 6.

Table 6 Location, sample size, coordinates, elevation, and source for the balsam fir samples and subalpine fir samples included in the microsatellite analysis of Fraser fir, intermediate fir, and balsam fir, with subalpine fir as an outgroup

\begin{tabular}{|c|c|c|c|c|c|c|}
\hline Location & State/province & Cluster & Long. & Lat. & Elev. (m) & Source \\
\hline \multicolumn{7}{|c|}{ Abies balsamea $(N=74)$} \\
\hline Canada Bay & Newfoundland & $\mathrm{MBF}$ & -56.13 & 50.72 & 0 & a \\
\hline Noel Paul Brook & Newfoundland & $\mathrm{MBF}$ & -56.62 & 48.53 & 330 & $\mathrm{~b}$ \\
\hline Hawkes Bay & Newfoundland & $\mathrm{MBF}$ & -57.17 & 50.60 & 0 & $\mathrm{a}$ \\
\hline Port Saunders & Newfoundland & $\mathrm{MBF}$ & -57.25 & 50.42 & 110 & $\mathrm{~b}$ \\
\hline North River & Nova Scotia & $\mathrm{MBF}$ & -60.77 & 46.42 & 425 & $\mathrm{~b}$ \\
\hline North Grant & Nova Scotia & $\mathrm{MBF}$ & -62.07 & 45.63 & 125 & $\mathrm{~b}$ \\
\hline Spar Lake & Nova Scotia & $\mathrm{MBF}$ & -62.38 & 45.08 & 61 & $\mathrm{~b}$ \\
\hline Woodfield & Nova Scotia & $\mathrm{CBF}$ & -62.42 & 45.53 & 200 & $\mathrm{~b}$ \\
\hline Sheet Harbor & Nova Scotia & $\mathrm{MBF}$ & -62.47 & 44.92 & 30 & $\mathrm{~b}$ \\
\hline Marie & Prince Edward Island & $\mathrm{MBF}$ & -62.65 & 46.40 & 30 & $\mathrm{~b}$ \\
\hline West River Road & Nova Scotia & $\mathrm{MBF}$ & -62.88 & 45.45 & 170 & $\mathrm{~b}$ \\
\hline Mermaid & Prince Edward Island & $\mathrm{CBF}$ & -63.03 & 46.27 & 8 & $\mathrm{~b}$ \\
\hline Onslow Mountain & Nova Scotia & WBF & -63.30 & 45.42 & 155 & $\mathrm{~b}$ \\
\hline Brookvale & Prince Edward Island & MBF & -63.42 & 46.28 & 9 & a \\
\hline
\end{tabular}


Table 6 continued

\begin{tabular}{|c|c|c|c|c|c|c|}
\hline Location & State/province & Cluster & Long. & Lat. & Elev. (m) & Source \\
\hline Farmington & Prince Edward Island & MBF & -63.48 & 46.38 & 9 & a \\
\hline Williamsdale & Nova Scotia & MBF & -63.90 & 45.60 & 250 & $\mathrm{~b}$ \\
\hline Richibucto & New Brunswick & MBF & -64.87 & 46.68 & 5 & $\mathrm{~b}$ \\
\hline Bishop Mountain & Nova Scotia & $\mathrm{MBF}$ & -64.98 & 45.03 & 175 & $\mathrm{~b}$ \\
\hline Mechanic Settlement & New Brunswick & WBF & -65.17 & 45.67 & 300 & $\mathrm{~b}$ \\
\hline Harewood & New Brunswick & $\mathrm{MBF}$ & -65.20 & 46.10 & 100 & $\mathrm{~b}$ \\
\hline Acadieville & New Brunswick & $\mathrm{MBF}$ & -65.30 & 46.67 & 80 & $\mathrm{~b}$ \\
\hline Fairview & New Brunswick & MBF & -65.40 & 45.40 & 120 & $\mathrm{~b}$ \\
\hline Big Salmon River & New Brunswick & $\mathrm{MBF}$ & -65.42 & 45.42 & 165 & $\mathrm{~b}$ \\
\hline Riviere Bonaventure & Quebec & $\mathrm{MBF}$ & -65.42 & 48.25 & 393 & $\mathrm{~b}$ \\
\hline Castaway & New Brunswick & $\mathrm{MBF}$ & -65.72 & 46.30 & 40 & $\mathrm{~b}$ \\
\hline Carleton & Nova Scotia & MBF & -65.93 & 44.02 & 61 & $\mathrm{~b}$ \\
\hline Sheephouse Brook & New Brunswick & $\mathrm{MBF}$ & -65.98 & 47.08 & 450 & $\mathrm{~b}$ \\
\hline Riviere Cascapedia & Quebec & MBF & -66.02 & 48.70 & 400 & $\mathrm{~b}$ \\
\hline Acadia Station & New Brunswick & WBF & -66.37 & 45.98 & 9 & a \\
\hline Peter Brook & New Brunswick & WBF & -66.37 & 45.98 & 9 & $\mathrm{a}$ \\
\hline Central Blissville & New Brunswick & MBF & -66.55 & 45.68 & 40 & $\mathrm{~b}$ \\
\hline Riviere Cap Chat & Quebec & $\mathrm{CBF}$ & -66.85 & 48.70 & 400 & $\mathrm{~b}$ \\
\hline Plaster Rock & New Brunswick & MBF & -67.13 & 46.92 & 200 & $\mathrm{~b}$ \\
\hline Canoose & New Brunswick & $\mathrm{MBF}$ & -67.38 & 45.35 & 100 & $\mathrm{~b}$ \\
\hline Green River & New Brunswick & $\mathrm{MBF}$ & -68.15 & 47.32 & 9 & a \\
\hline Bradley & Maine & $\mathrm{MBF}$ & -68.62 & 44.75 & 31 & c \\
\hline Cabano & Quebec & WBF & -69.02 & 47.52 & 274 & c \\
\hline Lac Rerock & Quebec & $\mathrm{MBF}$ & -69.33 & 50.02 & 395 & $\mathrm{~b}$ \\
\hline Petite-Lac-Ste-Anne & Quebec & $\mathrm{CBF}$ & -69.63 & 47.22 & 550 & $\mathrm{~b}$ \\
\hline St. Joseph & Quebec & $\mathrm{MBF}$ & -70.90 & 46.33 & 300 & $\mathrm{~b}$ \\
\hline Lac Etchemin & Quebec & $\mathrm{MBF}$ & -70.92 & 45.33 & 800 & $\mathrm{~b}$ \\
\hline Chicoutimi & Quebec & $\mathrm{MBF}$ & -71.08 & 48.32 & 130 & $\mathrm{~b}$ \\
\hline Bear Notch & New Hampshire & WBF & -71.32 & 44.03 & 486 & $\mathrm{~d}$ \\
\hline Saco River & New Hampshire & WBF & -71.35 & 44.12 & 306 & $\mathrm{~d}$ \\
\hline Gibbs Brook & New Hampshire & $\mathrm{CBF}$ & -71.41 & 44.22 & 599 & $\mathrm{~d}$ \\
\hline Kancamagus Pass & New Hampshire & WBF & -71.49 & 44.02 & 873 & $\mathrm{~d}$ \\
\hline Ricker Pond S.P. & Vermont & $\mathrm{CBF}$ & -72.24 & 44.24 & 331 & $\mathrm{~d}$ \\
\hline Mt. Mansfield & Vermont & $\mathrm{CBF}$ & -72.81 & 44.54 & 1,339 & $\mathrm{~d}$ \\
\hline Granville & Vermont & WBF & -72.87 & 44.00 & 457 & $\mathrm{c}$ \\
\hline Ripton & Vermont & $\mathrm{CBF}$ & -72.98 & 43.93 & 488 & $\mathrm{c}$ \\
\hline Mt. Greylock & Massachusetts & $\mathrm{MBF}$ & -73.17 & 42.64 & 964 & $\mathrm{~d}$ \\
\hline Lac Rouillard & Quebec & $\mathrm{CBF}$ & -73.82 & 48.42 & 0 & $\mathrm{~b}$ \\
\hline AuSable River & New York & $\mathrm{MBF}$ & -73.90 & 44.33 & 494 & $\mathrm{~d}$ \\
\hline Indian Lake & New York & $\mathrm{MBF}$ & -74.12 & 43.75 & 555 & $\mathrm{c}$ \\
\hline Ampersand Mountain & New York & $\mathrm{CBF}$ & -74.21 & 44.26 & 482 & $\mathrm{~d}$ \\
\hline Lake Eaton S.P. & New York & $\mathrm{MBF}$ & -74.46 & 43.99 & 529 & $\mathrm{~d}$ \\
\hline Lac Girard & Quebec & WBF & -74.53 & 45.68 & 120 & $\mathrm{~b}$ \\
\hline Lackawanna S.F. & Pennsylvania & $\mathrm{MBF}$ & -75.64 & 41.20 & 596 & $\mathrm{~d}$ \\
\hline Black Moshannon S.P. & Pennsylvania & $\mathrm{MBF}$ & -78.05 & 40.90 & 574 & $\mathrm{~d}$ \\
\hline Timmins & Ontario & WBF & -81.70 & 48.33 & 311 & $\mathrm{c}$ \\
\hline Mattice & Ontario & WBF & -83.33 & 49.58 & 245 & $\mathrm{c}$ \\
\hline Roscommon & Michigan & MBF & -84.80 & 44.50 & 351 & $\mathrm{c}$ \\
\hline
\end{tabular}


Table 6 continued

\begin{tabular}{|c|c|c|c|c|c|c|}
\hline Location & State/province & Cluster & Long. & Lat. & Elev. (m) & Source \\
\hline Garnet & Michigan & MBF & -85.40 & 46.25 & 255 & $\mathrm{c}$ \\
\hline Floodwood & Michigan & WBF & -87.93 & 46.20 & 412 & $\mathrm{c}$ \\
\hline Rhinelander & Wisconsin & $\mathrm{CBF}$ & -89.41 & 45.64 & 472 & $\mathrm{e}$ \\
\hline Park Falls & Wisconsin & WBF & -90.12 & 45.97 & 363 & $\mathrm{c}$ \\
\hline Ely & Minnesota & WBF & -91.78 & 47.95 & 488 & $\mathrm{c}$ \\
\hline Bluffton & Iowa & $\mathrm{CBF}$ & -91.90 & 43.40 & 325 & $\mathrm{~d}$ \\
\hline Isle & Minnesota & WBF & -93.45 & 46.20 & 354 & $\mathrm{c}$ \\
\hline Whiteshell Park & Manitoba & $\mathrm{CBF}$ & -96.12 & 50.25 & 265 & $\mathrm{c}$ \\
\hline Dauphin & Manitoba & MBF & -101.00 & 50.93 & 549 & $\mathrm{c}$ \\
\hline MacDonnell Lake & Saskatchewan & WBF & -105.27 & 54.00 & 495 & $\mathrm{f}$ \\
\hline Rocky/Clearwater Forest & Alberta & WBF & -114.82 & 52.80 & 990 & $\mathrm{~g}$ \\
\hline Rocky/Clearwater Forest & Alberta & WBF & -114.97 & 52.80 & 960 & $\mathrm{~g}$ \\
\hline \multicolumn{7}{|l|}{ Abies lasiocarpa $(N=10)$} \\
\hline Rocky/Clearwater Forest & Alberta & SAF & -115.00 & 52.80 & 1,585 & $\mathrm{~g}$ \\
\hline San Isabel N.F. & Colorado & SAF & -106.56 & 39.11 & 3,048 & $\mathrm{e}$ \\
\hline Apache N.F. & Arizona & SAF & -109.11 & 33.92 & 2,896 & $\mathrm{e}$ \\
\hline Monashee Mountains & British Columbia & SAF & -118.58 & 51.08 & 1,830 & $\mathrm{~b}$ \\
\hline McGillvray Lake & British Columbia & SAF & -119.85 & 50.85 & 1,448 & $\mathrm{~b}$ \\
\hline Bell Mountain & British Columbia & SAF & -120.32 & 53.32 & 1,175 & $\mathrm{~b}$ \\
\hline Valemount & British Columbia & SAF & -119.33 & 52.83 & 838 & $\mathrm{~b}$ \\
\hline Duck Lake & British Columbia & SAF & -124.65 & 49.12 & 1,130 & $\mathrm{~b}$ \\
\hline McKendrick Pass & British Columbia & SAF & -126.70 & 54.87 & 900 & $\mathrm{~b}$ \\
\hline Sakenichi & British Columbia & SAF & -125.90 & 55.12 & 1,000 & $\mathrm{~b}$ \\
\hline
\end{tabular}

$a$ Canadian Forest Service, $b$ National Tree Seed Centre of Canada, $c$ University of Vermont, $d$ K. M. Potter, $e$ Sheffield's Seed Company, $f$ Alberta Environmental Protection, $g$ Weyerhauser Canada

\section{References}

Alexander RB, Shearer RC, Shepperd WD (1990) Subalpine Fir. In: Burns RM, Honkala BH (eds) Silvics of North America: 1 conifers. U.S. Department of Agriculture, Washington DC

Allard HA, Leonard EC (1952) The Canaan and Stoney River Valleys of West Virginia, their former magnificent spruce forest, their vegetation and floristics today. Castanea 17:1-60

Amos W (2006) The hidden value of missing genotypes. Mol Biol Evol 23:1995-1996

Bakuzis EV, Hansen HL (1965) Balsam Fir: a monographic review. University of Minnesota Press, Minneapolis

Barton NH, Slatkin M (1986) A quasi-equilibrium theory of the distribution of rare alleles in a subdivided population. Heredity $56: 409-415$

Brookfield JFY (1996) A simple new method for estimating null allele frequency from heterozygote deficiency. Mol Ecol 5:453455

Bross-Fregonara N (2002) Study documents unique, but threatened balsam fir stands of WV's highlands. West Virginia Nongame Wildl Nat Herit News 18:5-6

Bush RM, Smouse PE (1992) Evidence for the adaptive significance of allozymes in forest trees. New For 6:179-196

Busing RT, White PS, MacKenzie MD (1993) Gradient analysis of old spruce-fir forests of the Great Smoky Mountains circa 1935. Can J Bot 71:951-958

Cavalli-Sforza LL, Edwards AWF (1967) Phylogenetic analysis: models and estimation procedures. Evolution 21:550-570
Chandler LM, Owens JN (2004) The pollination mechanism of Abies amabilis. Can J For Res 34:1071-1080

Chapuis MP, Estoup A (2007) Microsatellite null alleles and estimation of population differentiation. Mol Biol Evol 24:621-631

Clark CM, Wentworth TR, O'Malley DM (2000) Genetic discontinuity revealed by chloroplast microsatellites in eastern North American Abies (Pinaceae). Am J Bot 87:774-782

Clarkson RB (1966) The vascular flora of the Monongahela National Forest, West Virginia. Castanea 31:1-119

Clarkson RB, Fairbrothers DE (1970) A seriological and electrophoretic investigation of eastern North American Abies (Pinaceae). Taxon 19:720-727

Corander J, Waldmann P, Sillanpaa MJ (2003) Bayesian analysis of genetic differentiation between populations. Genetics 163: 367-374

Corander J, Siren J, Arjas E (2008) Bayesian spatial modeling of genetic population structure. Computation Stat 23:111-129

Core EL (1934) The blister pine in West Virginia. Torreya 34:92-93

Critchfield WB (1984) Impact of the Pleistocene on the genetic structure of North American conifers. In: Lanner RM (ed) Proceedings of the Eighth North American Forest Biology Workshop. Department of Forest Resources, Utah State University, Logan, pp 70-118

Davis MB (1981) Quaternary history and the stability of forest communities. In: Shugart HH, Botkin DB, West DC (eds) Forest succession, concepts and applications. Springer, New York, pp 132-154 
Delcourt HR, Delcourt PA (1984) Late-Quaternary history of the spruce-fir ecosystem in the Southern Appalachian region. In: White PS (ed) The Southern Appalachian Spruce-Fir ecosystem: its biology and threats. United States Department of the Interior, National Park Service, Atlanta, pp 22-35

Delcourt PA, Delcourt HR (1987) Long-term forest dynamics of the temperate zone. Springer, New York

Delcourt PA, Delcourt HR (1998) Paleoecological insights on conservation of biodiversity: a focus on species, ecosystems, and landscapes. Ecol Appl 8:921-934

Dull CW, Ward JD, Brown HD et al (1988) Evaluation of Spruce and Fir mortality in the Southern Appalachian mountains. United States Department of Agriculture, Forest Service, Southern Region, Atlanta

Eager C (1984) Review of the biology and ecology of the balsam woolly aphid in Southern Appalachian spruce-fir forests. In: White PS (ed) The Southern Appalachian Spruce-Fir ecosystem: its biology and threats. United States Department of the Interior, National Park Service, Atlanta, pp 36-50

ESRI (2006) ArcMap 9.2. Environmental Systems Research Institute, Redlands

Farjon A, Rushforth KD (1989) A classification of Abies Miller (Pinaceae). Notes RBG Edinb 46:59-79

Felsenstein J (2005) PHYLIP (Phylogeny Inference Package), version 3.6. Department of Genome Sciences, University of Washington, Seattle

Fraser DJ, Bernatchez L (2001) Adaptive evolutionary conservation: towards a unified concept for defining conservation units. Mol Ecol 10:2741-2752

Fulling EH (1936) Abies intermedia, the Blue Ridge fir, a new species. Castanea 1:91-94

Gao H, Williamson S, Bustamante CD (2007) A Markov chain Monte Carlo approach for joint inference of population structure and inbreeding rates from multilocus genotype data. Genetics 176:1635-1651

Goudet J (1995) FSTAT (Version 1.2): a computer program to calculate F-statistics. J Hered 86:485-486

Hamrick JL, Godt MJW (1996) Effects of life history traits on genetic diversity in plant species. Philos T Roy Soc B 351:1291-1298

Hawley GJ, Dehayes DH (1985a) Hybridization among several NorthAmerican firs: 2. Hybrid verification. Can J For Res 15:50-55

Hawley GJ, Dehayes DH (1985b) Hybridization among several North American firs: 1. Crossability. Can J For Res 15:42-49

Hewitt GM (1996) Some genetic consequences of ice ages, and their role in divergence and speciation. Biol J Linn Soc 58:247-276

Hollingsworth RG, Hain FP (1991) Balsam woolly adelgid (Homoptera, Adelgidae) and spruce-fir decline in the Southern Appalachians: assessing pest relevance in a damaged ecosystem. Fla Entomol 74:179-187

Hunt RS, von Rudloff E (1974) Chemosystematic studies in the genus Abies. I. Leaf and twig oil analysis of alpine and balsam firs. Can J Bot 52:477-487

Jacobs B, Werth CR, Gutman SI (1984) Genetic relationships in Abies (fir) of eastern United States: an electrophoretic study. Can J Bot 62:609-616

Josserand S, Potter KM, Johnson G et al (2006) Isolation and characterization of microsatellite markers in Fraser fir (Abies fraseri). Mol Ecol Notes 6:65-68

Klaehn FU, Winieski JA (1962) Interspecific hybridization in the genus Abies. Silvae Genet 11:130-142

Lester DT (1968) Variation in cone morphology of balsam fir, Abies balsamea. Rhodora 70:83-94

Lester DT (1970) Variation in seedling development of balsam fir associated with seed origin. Can J Bot 48:1093-1097

Lester DT (1974) Geographic variation in leaf and twig monoterpenes of balsam fir. Can J For Res 4:55-60
Lester DT, Mohn CA, Wright JW (1976) Geographic variation in balsam fir: 11-year results in the Lake States. Can J For Res 6:389-394

Lewis PO, Zaykin D (2001) GDA (Genetic Data Analysis): computer program for the analysis of allelic data

Lexer C, Fay MF, Joseph JA et al (2005) Barrier to gene flow between two ecologically divergent Populus species, P. alba (white poplar) and $P$. tremula (European aspen): the role of ecology and life history in gene introgression. Mol Ecol 14:1045-1057

Liu T-S (1971) A monograph of the genus Abies. Department of Forestry, College of Agriculture, National Taiwan University, Taipei

Marty TL, Guries RP, Mohn CA, et al. (1983) Fifteen-year results of a balsam fir provenance in the Lake States. Proceedings of the third north central Forest Tree Improvement Conference. Wooster, Ohio, pp 14-23

Mazzeo PM (1966) Notes on the conifers of the Shenandoah National Park. Castanea 31:240-247

McDonald BR (1993) Rare plants of the upland forests. In: Stephenson SL (ed) Upland forests of West Virginia. McClain Printing Co., Parsons, pp 67-85

Moritz C (1994) Defining evolutionarily significant units for conservation. Trends Ecol Evol 9:373-375

Myers OJ, Bormann FH (1963) Phenotypic variation in Abies balsamea in response to altitudinal and geographic gradients. Ecology 44:429-436

NatureServe (2009) NatureServe Explorer: an online encyclopedia of life [web application]. Version 7.1. NatureServe http://www. natureserve.org/explorer. Accessed 20 July 2009

Neale DB, Adams WT (1985) Allozyme and mating system variation in balsam fir (Abies balsamea) across a continuous elevational transect. Can J Bot 63:2448-2453

Parker WH, Maze J, Bradfield GE (1981) Implications of morphological and anatomical variation in Abies balsamea and Abies lasiocarpa (Pinaceae) from western Canada. Am J Bot 68:843854

Parker WH, Maze J, Bennett FE et al (1984) Needle flavonoid variation in Abies balsamea and Abies lasiocarpa from western Canada. Taxon 33:1-12

Potter KM, Frampton J, Josserand SA et al (2008) Genetic variation and population structure in Fraser fir (Abies fraseri): a microsatellite assessment of young trees. Can J For Res 38:2128-2137

Pritchard JK, Stephens M, Donnelly P (2000) Inference of population structure using multilocus genotype data. Genetics 155:945-959

Raymond M, Rousset F (1995) Genepop (Version-1.2): population genetics software for exact tests and ecumenicism. J Hered 86:248-249

Reddington EB, McCormack ML Jr (1976) Monoterpene variability on balsam fir (Abies balsamea (L.) Miller) provenances. Proceedings of the 23rd Northeastern Forest Tree Improvement Conference. Rutgers University, New Brunswick, pp 165-174

Rheinhardt RD (1984) Comparative study of composition and distribution patterns of subalpine forests in the Balsam Mountains of southwest Virginia and the Great Smoky Mountains. B Torrey Bot Club 111:489-493

Robinson JF, Thor E (1969) Natural variation in Abies of the Southern Appalachians. For Sci 15:238-245

Robson KA, Maze J, Scagel RK et al (1993) Ontogeny, phylogeny and intraspecific variation in North American Abies Mill (Pinaceae): an empirical approach to organization and evolution. Taxon 42:17-34

Roe G (1995) Transplanting Red Spruce and Balsam Fir: part of the restoration effort at Shenandoah National Park. U.S. Department of the Interior, National Park Service, Luray

Roller KJ (1966) Resin canal position in needles of balsam, alpine and Fraser firs. For Sci 12:348-355 
Ross RK (1988) Patterns of allelic variation in natural populations of Abies fraseri. Department of Forestry, North Carolina State University, Raleigh

Schwartz MW, Iverson LR, Prasad AM et al (2006) Predicting extinctions as a result of climate change. Ecology 87:1611-1615

Siegismund HR, Jensen JS (2001) Intrapopulation and interpopulation genetic variation of Quercus in Denmark. Scand J For Res 16:103-116

Stephenson SL, Adams HS (1986) An ecological study of balsam fir communities in West Virginia. Bull Torrey Bot Club 113: 372-381

Takezaki N, Nei M (1996) Genetic distances and reconstruction of phylogenetic trees from microsatellite DNA. Genetics 144: 389-399

Thor E, Barnett PE (1974) Taxonomy of Abies in the Southern Appalachians: variation in balsam monoterpenes and wood properties. For Sci 20:32-40

Townsend JF (2009) Natural heritage resources of Virginia: rare plants. Virginia Department of Conservation and Recreation, Division of Natural Heritage, Richmond

van Oosterhout C, Hutchinson WF, Wills DPM et al (2004) MicroChecker: software for identifying and correcting genotyping errors in microsatellite data. Mol Ecol Notes 4:535-538
Watts WA (1979) Late Quaternary vegetation of central Appalachia and the New Jersey coastal plain. Ecol Monogr 49:427-469

Weir BS, Cockerham CC (1984) Estimating F-statistics for the analysis of population structure. Evolution 38:1358-1370

West Virginia Natural Heritage Program (2003) Rare, threatened and endangered plants. West Virginia Division of Natural Resources http://www.wvdnr.gov/Wildlife/PDFFiles/Plantsnew.pdf. Accessed 20 July 2009

Whitehead DR (1973) Late-Wisconsin vegetational changes in unglaciated eastern North America. Quat Res 3:621-631

Whittaker RH (1956) Vegetation of the Great Smoky Mountains. Ecol Monogr 26:1-80

Zavarin E, Snajberk K (1972) Geographical variability of monoterpenes from Abies balsamea and Abies fraseri. Phytochemistry 11:1407-1421

Zavarin E, Snajberk K, Reichert T et al (1970) On the geographic variability of the monoterpenes from the cortical blister oleoresin of Abies lasiocarpa. Phytochemistry 9:377-395

Ziegenhagen B, Bialozyt R, Liepelt S (2004) Contrasting molecular markers reveal: gene flow via pollen is much more effective than gene flow via seeds. In: Werner D (ed) Biological resources and migration. Springer, Berlin, pp 239-251 